\title{
"Treason is Treason": The Iowa American Legion and the Meaning of Disloyalty after World War I
}

\section{CHRISTOPHER NEHLS}

IN THE SUMMER OF 1921 longtime woman suffrage activist and Socialist Ida Crouch-Hazlett joined other Socialist Party members on a speaking tour to build support for the release of wartime federal political prisoners. ${ }^{1}$ Crouch-Hazlett's route took her through Iowa, where she spoke at open-air meetings in cities and small towns. Along her tour, members of the American Legion harassed her and interrupted her speeches. At times the interruptions became violent, both toward the crowds her speeches attracted and toward Crouch-Hazlett herself. On several occasions Legionnaires abducted her. Despite the harassment, Crouch-Hazlett continued her tour undaunted and challenged her assailants' usurpation of her constitutional rights.

The controversy between the Iowa American Legion and Ida Crouch-Hazlett took place during a period when Iowansand Americans as a whole-were struggling to define the relationship between civil liberties and loyalty to the nation. During the years surrounding World War I many Americans accepted the principle that their fellow citizens' disloyal words and thoughts could do the nation as much harm as disloyal acts.

1. Des Moines Register, 8/13/1921.

Research for this article was supported by a 2005-2006 State Historical Society of Iowa Research Grant.

THE ANNALS OF IOWA 66 (Spring 2007). (C) The State Historical Society of Iowa, 2007. 
They accordingly accepted the curtailment of nonconformists' civil liberties. Legionnaires' interruptions of Crouch-Hazlett's speeches on the grounds that she uttered disloyal phrases were not much different in style and motivation from innumerable similar instances during this period in American history.

Concern that left-wing radical speech could destroy the American social fabric actually arose before American entrance into World War I. Many communities west of the Mississippi denied free speech rights to members of the Industrial Workers of the World (IWW). Local business interests, while spearheading such efforts, claimed that the IWW abused the American tradition of freedom of speech by using it as a cover for its revolutionary efforts. During the war, Americans from President Woodrow Wilson down to the average citizen insisted that "disloyal" opinion be purged from public discourse and its purveyors punished to ensure the success of the war effort. The Espionage and Sedition Acts expanded federal prosecutorial power to do exactly that. Citizen vigilantes took up the work of enforcing loyalty on their own, frequently confronting suspected German sympathizers and antiwar leftists. Such confrontations sometimes turned violent, but the activities were often less visible, such as checking up on whether local men had registered for the draft, pressuring wavering citizens to buy war bonds, and turning over to law enforcement those suspected of being "pro-German." 2

This debate about how to reconcile loyalty and civil liberties persisted after the war. Historian Paul Murphy has argued that freedom of speech in the immediate postwar period "was a useful key to the ambitions of various groups struggling for immediate power and seeking to define the symbols of democracy so as to make best use of them for an indefinite future period." Conservatives attacked the right of radicals to bring supposedly

2. Frank Tobias Higbie, Indispensable Outcasts: Hobo Workers and Community in the American Midwest, 1880-1930 (Urbana, IL, 2003); Greg Hall, Harvest Wobblies: The Industrial Workers of the World and Agricultural Laborers in the American West, 1905-1930 (Corvallis, OR, 2001); David M. Kennedy, Over Here: The First World War and American Society (New York, 1980), 75-88; H. C. Peterson and Gilbert C. Fite, Opponents of War, 1917-1918 (Madison, WI, 1957); Christopher Capozzola, "The Only Badge Needed Is Your Patriotic Fervor: Vigilance, Coercion and the Law in World War I," Journal of American History 99 (2002), 1354-82. 
foreign and therefore "un-American" ideas into American political culture, while radicals defended themselves with the aegis of a traditional and broad interpretation of the First Amendment. ${ }^{3}$

An analysis of the Iowa Legionnaires' activities during Ida Crouch-Hazlett's Iowa tour provides insight into how the clash taking place in the wider postwar American political culture transpired at the grassroots. As Crouch-Hazlett played her part in trying to re-establish the legitimacy of socialism after its wartime repression, she ran up against an organization committed to shaping the political culture to its own liking. Founded in early 1919, the American Legion hoped to make wartime vigilance against disloyalty a permanent aspect of American civic life. It was one of several organizations, including the revitalized $\mathrm{Ku}$ Klux Klan, that used confrontational and vigilante tactics held over from the war to control the public sphere. ${ }^{4}$ Organized by men with strong ties to American business and supported by an affluent membership base, the Legion focused its vigilante energies specifically on leftist radical groups. Legionnaires helped to crush the remnants of the IWW after the war, using a bloody confrontation between an American Legion post in Centralia, Washington, and IWW members to legitimize its efforts. ${ }^{5}$ Posts also raided radical newspapers and meeting halls, intervened to break strikes in the name of preserving "law and order," and interrupted speeches of a variety of prominent radicals, such as Victor Berger, Ella Reeve Bloor, and Kate Richards O'Hare. ${ }^{6}$

Legionnaires paid so much attention to radicals' activities during the first few years after the war not because they feared imminent revolution but because radicals violated the class-free conception of citizenship at the heart of their organization's notion of the nation's democratic identity. With a socially elite

3. Paul L. Murphy, The Meaning of Freedom of Speech: First Amendment Freedoms from Wilson to FDR (Westport, CT, 1972), 25-37 (quotation on 25).

4. Capozzola, "The Only Badge Needed," 1379.

5. Tom Copeland, The Centralia Tragedy of 1919: Elmer Smith and the Wobblies (Seattle, 1993); Melvyn Dubofsky, We Shall Be All: A History of the Industrial Workers of the World, 2nd ed. (Urbana, IL, 1988), 455-56.

6. William Pencak, For God and Country: The American Legion, 1919-1941 (Boston, 1989), 74, 146-62, 209-17; Arthur Warner, "The Truth about the American Legion," Nation, 7/6/1921, 7-10; Sally M. Miller, From Prairie to Prison: The Life of Social Activist Kate Richards O'Hare (Columbia, MO, 1993), 195-96. 
leadership clique and a largely middle-class membership base, the Legion rejected the principle of class consciousness as a legitimate motivation for political activity. To Legionnaires, working-class consciousness upset the equality of opportunity they believed was inherent in the American democratic system. This condition of equality united all citizens by allowing each, regardless of social background, to succeed politically or financially. The Legion rejected "the autocracy of both the classes and the masses," as it stated in the preamble of its constitution. ${ }^{7}$ Its members, in turn, regarded any political party or movement that endorsed American workers' class consciousness to be anathema to the nation's exceptional democratic essence.

The Legionnaires' vigilante tendencies against radicals, on display in Iowa in 1921, were part of its fundamental mission to connect Americans to a clearly defined and ideologically static idea of what it meant to be part of the nation and what political and civic behaviors were expected of them. Its members used vigilantism to defend their shared vision of national identity. For Legionnaires, moments such as the arrival of speakers or organizers from out of town could produce a kind of nationalist theater in which patriotic citizens could directly confront "unAmerican" influence infiltrating their community. Such demonstrations clearly marked for all citizens what kinds of civic behaviors and political ideologies were consistent with the nation's true identity. Iowa Legionnaires' rude treatment of Ida Crouch-Hazlett in the summer of 1921 reveals part of a larger story of how veterans tried to shape the ideological contours of American political culture and redefine the rules of political participation after World War I.

Legionnaires followed a pattern of action that matched a traditional definition of vigilantism as a local defense against perceived challengers to the social, political, or moral order in the absence of strong state enforcement power. ${ }^{8}$ Although the

7. Preamble, Constitution of the American Legion, www.legion.org/?section= our_legion\&subsection $=$ ol_who_we_are\&content $=$ ol_who_we_are, accessed 12/19/2007. See also Gary Gerstle, American Crucible: Race and Nation in the Twentieth Century (Princeton, NJ, 2001).

8. In particular, Legionnaires' efforts to challenge working-class groups roughly correspond to Richard Maxwell Brown's concept of "neo-vigilantism," or the "application of vigilantism to the problems of an emerging urban, in- 
Legion drew from a deep tradition of citizen policing of the public sphere, by World War I Americans were becoming increasingly uncomfortable with the more violent methods of some American vigilantes. Many considered acts such as the lynching of Robert Prager for his perceived support of the German war cause in April 1918 not as the protection of "law and order" but as its usurpation by the mob. Despite rejecting mob rule, they did not settle the issue during the war of how far legitimate coercion could go. As historian Christopher Capozzola has written, the idea that citizens "had some positive obligation to police one another was never fully challenged" during the war. The line between legitimate vigilance by self-empowered citizens and illegitimate vigilantism by mobs was unclear in the war period and remained so in the years that followed. ${ }^{9}$ Equally unclear was what would constitute disloyalty worthy of citizen intervention now that the guns of war were silent. In that period of transition, the Legion claimed that its members pursued legitimate activity when intervening to suppress speech or assembly that threatened the social order or the ability of government to maintain a loyal following. Legionnaires acted on behalf of a distant state, ensuring the loyalty of citizens in their communities. Whether or not citizens agreed with the Legion's claims to legitimacy in such episodes, veterans believed that it was their charge to do so.

In the controversies that arose from their gruff treatment of Crouch-Hazlett along her speaking tour, Iowa Legionnaires argued that they were not, as she and her supporters claimed, interfering with her freedom of speech. Rather, the Legion claimed that it acted because Crouch-Hazlett had espoused inflammatory, "disloyal" opinions targeted at the American system of government. The organization's vigilantism in this re-

dustrial, racially and ethnically diverse America." Richard Maxwell Brown, Strain of Violence: Historical Studies in American Violence and Vigilantism (New York, 1975); idem, "The History of Vigilantism in America," in H. Jon Rosenbaum and Peter C. Sederberg, eds., Vigilante Politics (Philadelphia, 1976), 99.

9. Capozzola, "The Only Badge Needed," 1354-56; idem, "Uncle Sam Wants You: Political Obligations in World War I America" (Ph.D. diss., Columbia University, 2002), 180-84 (quotation on 184); Gerstle, American Crucible, 56, 6677; Gary Gerstle, "Liberty, Coercion, and the Making of Americans," Journal of American History 84 (1997), 530-31. 
gard matched the state's own outlook on freedom of speech in this era. Courts developed the "bad tendency doctrine" during the war, granting the state the authority to control speech that might create social disorder. Iowa passed its own broadly drawn sedition law in 1917, creating a model for other states that passed similar legislation. After the war, states passed expansive criminal syndicalism laws designed to curtail the freedom of radical unions and political parties and to make their organizing efforts much more difficult. The pushback from liberal groups would ultimately even out the sides of the debate over the nature of the freedom of speech later in the 1920s, but in the early part of the decade the Legion's view on free speech fell within the mainstream of American public opinion. ${ }^{10}$ That did not mean, however, that vigilantism in reaction to opinion outside the mainstream was without controversy.

Legionnaires tried to permanently extend wartime standards of what was acceptable to coerce conformity in American political life. In doing so, the Legion claimed that behavior and opinions it found in conflict with its Americanism were not simply bad citizenship but active disloyalty to the nation, regardless of whether or not the nation faced a particular crisis such as war. Hence, its claim that Crouch-Hazlett represented "un-American" ideas was more than a simple rhetorical flourish; it was an indictment of those ideas' acceptability within the American democratic system and marked them as corrosive to the political culture and illegitimate as such. Iowans and Americans who subscribed to them were forfeiting their place in the nation.

WHEN IDA CROUCH-HAZLETT arrived in Iowa in 1921, she was, at age 58, a veteran organizer, publicist, and activist for social justice causes. Educated at Stanford and the Chicago Mu-

10. Kathleen Kennedy, Disloyal Mothers and Scurrilous Citizens: Women and Subversion during World War I (Bloomington, IN, 1999), xiii-xiv; Murphy, The Meaning of Free Speech, 41-44, 46-57. For a survey of criminal syndicalism laws, see Eldridge Foster Dowell, A History of Criminal Syndicalism Legislation in the United States (Baltimore, 1939). Iowa's 1917 sedition law punished inciting or attempting to incite an insurrection, advocating the destruction or subversion of the U.S. or Iowa government, and attempting to create hostility to those governments. Murphy, The Meaning of Free Speech, 41. 


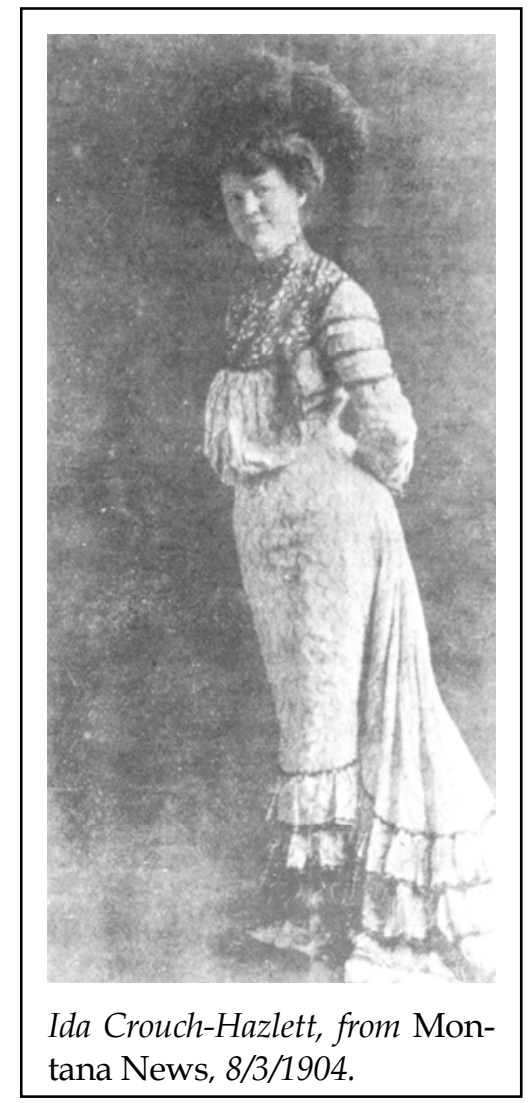

sical College, she had been active in a wide variety of reform movements at the turn of the twentieth century. Crouch-Hazlett had belonged to the Knights of Labor and the American Labor Union in her youth. Her real passion, however, was for the woman suffrage movement. She served on the national board of the National American Woman Suffrage Association, touring at the turn of the century with suffragists such as Susan B. Anthony and Carrie Chapman Catt. Besides being a tireless organizer and advocate for the cause, she tried to advance women's political power through her own person. She first ran for office on the Prohibition Party ticket for a seat on the county school board in her native Illinois and tried again in Denver on Prohibition and Populist party tickets. In 1901 Crouch-Hazlett joined the Socialist Party as an organizer and lecturer, becoming part of 
a wing of Socialists from the Mountain West and Great Plains states (a group that included Eugene Debs) that tried to make woman suffrage a major plank of the party's platform. A year after she joined she became the first woman to run for Congress on the Socialist Party ticket in Colorado. After her attempts at a career as an elected official, Crouch-Hazlett worked as an editor and writer for a variety of Socialist and labor newspapers in the Mountain West and Midwest. By 1921, she had 20 years of experience as a lecturer for the Socialist Party. ${ }^{11}$

Crouch-Hazlett's arrival in the Socialist Party through other reform agendas mirrored the experience of many women of the American Left, particularly those removed from immigrantinspired East Coast Socialist circles. Such women saw socialism as a moral reform cause rather than a sterile economic argument. They tended to see their own role in the movement through a late nineteenth-century frame that cast female political activism as bringing feminine standards of morality to a political system in need of redemption. Their activism was designed in part to publicly shame Americans into doing better. Crouch-Hazlett shared a political style with another victim of Legion vigilantism, Kate Richards O'Hare, whose charismatic and almost evangelical speaking style on issues important to socialists contrasted sharply with the eastern party establishment, which focused on organization building. ${ }^{12}$

Crouch-Hazlett's radical politics and rhetorical style made her a likely target of Legionnaires' vigilantism in Iowa. Her reliance on public spectacle and barnstorming speaking toursperhaps borrowed from the old Populist movement-played into the Legion's tactic of using dramatic confrontations with outside agitators to put its principles of nationalism and loyalty on display. Crouch-Hazlett's résumé hardly made her a Bolshevist revolutionary, but her enthusiasm for the Socialist Party and support for Eugene Debs's release from federal prison marked

11. Solon DeLeon, ed., The American Labor Who's Who (New York, 1925), 51-52; Mary Jo Buhle, Women and American Socialism, 1870-1920 (Urbana, IL, 1981), 215-17, 241; Des Moines Register, 8/13/1921.

12. Paula Baker, "The Domestication of Politics: Women and American Political Society, 1780-1920," American Historical Review 89 (1984), 620-74; Kennedy, Disloyal Mothers and Scurrilous Citizens, 18-38. 
her as suspicious in Legionnaires' eyes. Many in the Legion conflated the Socialist Party's calls for public ownership of some industry, its class-focused political agenda, and some leaders' opposition to American entrance into the Great War with the agenda of the Bolshevist revolutionaries in Russia. Some Legionnaires drew the conclusion that any left-wing party was connected to a broader Communist conspiracy emerging in Moscow. Even more sober-minded Legionnaires still vehemently opposed the release of those convicted under the wartime Espionage Act from federal jails, Debs chiefly among them. As the Legion's adjutant for Kentucky commented during the Debs pardon controversy, allowing pacifists and war protestors off the hook made "patriotism and loyalty to our country in times of war a pretty compliment rather than a stern necessity." 13 The Legion successfully challenged a Socialist campaign to drum up public support for amnesty in the winter of 1919. Posts in the Socialist strongholds of Reading, Pennsylvania, and Elmira, New York, forced the cancellation of speeches and demonstrations by Socialists. Legion intimidation ensured meager support for a Socialist march for amnesty up Fifth Avenue in Manhattan on Christmas Day. The campaign soon fizzled. ${ }^{14}$

The Iowa Legion's attacks on Crouch-Hazlett also had a gendered component that reflected broader biases within the national organization. Although the Legion did not oppose woman suffrage, it argued implicitly in many ways during the 1920s for the superiority of male citizenship over female by virtue of intrinsic differences between the sexes. The veterans who joined the Legion believed that it was men who had built the nation and led it to glory. The Legion accepted female members but only through subsidiary membership in its Ladies Auxiliary, a body that was designed more to reflect women's patriotism off of the heroic men whose kinship relation was required for their membership. During patriotic holidays, Legionnaires put the heroism and civic virtue of male veteran citizens on display as exemplars for other Americans to follow. Much of the or-

13. Quoted in Pencak, For God and Country, 158.

14. John Sherman, “'This Is a Crusade!': Socialist Party Amnesty Campaigns to Free Eugene V. Debs, 1919-1921," in Ronald C. Kent et al., eds., Culture, Gender, Race, and U.S. Labor History (Westport, CT, 1993), 27-29. 
ganization's civic work, ranging from Get Out the Vote drives to sponsoring youth baseball teams and Boy Scout troops, concentrated primarily on improving the civic involvement of men and boys. Legionnaires and auxiliary members also viciously attacked the patriotism and fitness for citizenship of women's pacifist organizations. The women in such organizations challenged the Legion's connection between strong national defense and the quality of the nation's male citizenry, which Legionnaires believed was the key to American national greatness. Prominent Iowa Legionnaire Hanford MacNider dismissed the women of such organizations as offering "'sob sister' pacifism" and echoed a familiar Legion claim that pacifists were merely Communist stooges. A chapter of the Women's International League for Peace and Freedom faced a vociferous challenge from Legion and Legion Auxiliary members when it tried to form in Sioux City in 1926, to large degree because the pacifists challenged the community's male-dominated consideration of American citizenship. ${ }^{15}$

Legionnaires in Iowa had engaged a variety of radicals before Crouch-Hazlett began her 1921 tour. Veterans from the Monahan Post of Sioux City gathered and repeatedly interrupted a speech by IWW leader "Big Bill" Haywood that he delivered from a window to a crowd outside the local IWW hall during the Wobblies' 1919 convention in the city. Post commander Robert Pike blamed Sioux City mayor Wallace Short for Haywood's presence in the city and for breaking a promise the mayor had made not to allow the IWW to distribute handbills on city streets. Short's perceived friendliness to the IWW led the Iowa Legion to choose Cedar Rapids rather than Sioux City for its 1920 convention. Legionnaires in Clinton, Iowa, protested a Memorial Day picnic by members of the Labor Party in Clinton, Iowa. After failing to convince the mayor to ban the meeting, Legion members gathered with town businessmen and tried to

15. Francesca Morgan, Women and Patriotism in Jim Crow America (Chapel Hill, NC, 2005); Christopher C. Nehls, "A Grand and Glorious Feeling: The American Legion and American Nationalism between the World Wars" (Ph.D. diss., University of Virginia, 2007); Liette Gidlow, The Big Vote: Gender, Consumer Culture, and the Politics of Exclusion, 1890s-1920s (Baltimore, 2004); Kim E. Nielsen, "Dangerous Iowa Women: Pacifism, Patriotism, and the Woman-Citizen in Sioux City, 1920-1927," Annals of Iowa 56 (1997), 80-98 (quote on 88). 
verbally disrupt a speech by Chicago Labor Party leader Edward Ellis Carr.16

As these early antiradical actions demonstrated, the Iowa American Legion drew considerable support from the state's professional and business classes in growing cities and towns. Iowa became a base of support for the American Legion as it grew in the early 1920s. By the end of the summer of CrouchHazlett's tour, the Legion had established 575 posts in Iowa with a total membership of 41,044 by September 1, 1921. Large posts formed in some of the more populous cities in the state, such as Des Moines, Sioux City, and Cedar Rapids, but the bulk of the Iowa Legion's membership came from posts in small communities scattered across the state. ${ }^{17}$

Its success in such communities reflected the overlapping understandings of obligation that veterans held and that Americans had demonstrated in their locally focused volunteerism and vigilance activities during the war. Local activism was the first stage in building a national conception of citizenship obligation, and the post-centered structure of the Legion worked particularly well in the scattered small cities and towns in the Midwest. The men who joined in these locales, most often professional men, merchants, or craftsmen, imagined themselves the rightful centers of civic life. The organization's growth in Iowa mirrored its success elsewhere in the upper Midwest. States such as Iowa, Wisconsin, and Minnesota were critical to the organization's overall growth, which had reached three-quarters of a million veterans by $1921 .{ }^{18}$

16. William H. Cumberland, Wallace M. Short: Iowa Rebel (Ames, 1983), 59-60; New Majority (Chicago), 6/12/1920, American Civil Liberties Union Papers (microfilm), reel 22, vol. 154, Mudd Library, Princeton University, Princeton, NJ (hereafter cited as ACLU Papers).

17. The Iowa department also enjoyed strong early leadership that bolstered its spread across the state. National Republican Party leader and Mason City native Hanford MacNider had served as an early national organizer in the organization along with fellow Republicans Theodore Roosevelt Jr., Hamilton Fish Jr., and Eric Fisher Wood. After serving as the Iowa Department Commander, MacNider became National Commander in 1921. By 1921 the Iowa Department also had established a fine newspaper under the editorship of Frank Miles. Pencak, For God and Country, 36-37, 112-14.

18. Proceedings of the Third Annual State Convention of the Iowa Department, The American Legion, Spirit Lake, IA. Sept. 1-3, 1921, American Legion Iowa De- 
CROUCH-HAZLETT'S FIRST RUN-IN with the American Legion in Iowa came on July 23, 1921, in Newton, where she was scheduled to give a speech on unemployment and political prisoners in federal jails. As she began her address in front of the local courthouse, members of a local Legion post led a crowd of townspeople that pushed their way to the front of her audience. They interrupted her speech with yells, horn blasts, and the racket of banging on tin pans. According to one report, someone in the crowd admonished Crouch-Hazlett to kiss the American flag "and say she liked it," an act reminiscent of mob confrontations with citizens of questionable loyalty during the war. The crowd then escorted Crouch-Hazlett back to the home where she was staying, and the local police force ushered her to an awaiting train. In her speech, a local editorialist claimed, Crouch-Hazlett had stated that government "'of the people, for the people and by the people' was a fake, had never been true, was not true today nor would it ever be true. In fact, to hear her tell it and accept her views, one would think that the nation's government was about the worst that ever existed and that in order to go to the land of paradise one would need have to travel to the land of Soviet Russia - the land of eternal bliss." CrouchHazlett's speech, in other words, "was not good Americanism." 19

From Newton, Crouch-Hazlett journeyed to Des Moines the next day for another speaking engagement. Upon her arrival, city Chief of Police R. C. Saunders warned her to cancel her speech. Crouch-Hazlett ignored the warning, and that afternoon she and three local Socialist Party members were hauled off to jail for disturbing the peace. Socialist Carl Moll was reading from the Declaration of Independence at the time of the arrests, and Saunders claimed he had disrespected the document. When Crouch-Hazlett and her fellow Socialists were released the following day, she planned another speech on the steps of the city library amid rumors that she would be expelled from town for her disloyal views. As she mounted the steps of the li-

partment Records, State Historical Society of Iowa, Iowa City; Nehls, "A Grand and Glorious Feeling," 82-83. The Legion did not keep demographic information on its own members until the 1930s.

19. New Day, 8/6/1921; Council Bluffs Nonpareil, 7/28/1921; Des Moines Register, 7/25/1921; Newton Record, 7/29/1921 (quoted). 
brary, members of the Argonne Post of the American Legion, led by Irving Femrite, snatched Crouch-Hazlett and whisked her to an awaiting car. Under police escort, the Legionnaires drove her to a police station, where she remained until that evening, having refused the Legionnaires' offer to drive her back to her hotel. After the fact, the Legionnaires claimed that they had abducted Crouch-Hazlett for her own safety after catching word of a plot by persons unknown to disrupt the meeting violently. No plotters materialized, however. With both of her speaking engagements in Des Moines interrupted, Crouch-Hazlett decided to stick with her schedule and travel to Fort Dodge the next day and return to Des Moines in August rather than upset her entire tour. ${ }^{20}$

The Socialist and unionist communities of Des Moines immediately called on the Argonne Post to distance itself from the vigilantism of some of its members. Both groups saw CrouchHazlett's trouble with the Legion as a freedom of speech issue, with the Legion stuck in a wartime mindset about what the Socialist Party represented and the need to defend the nation from disloyalty. Union supporters in Des Moines were also suspicious of the Legion's connections to local business. The incident at the library had come a week after Legionnaires were alleged to have participated along with police in a roundup at a Des Moines rail yard of 14 workers suspected of being members of the IWW. It seemed, therefore, that the Legion was supporting business interests in the state in their drive to institute the open shop. While not condemning the Legion as an organization, a resolution passed by the Trades and Labor Assembly called on the Legion and the city council to condemn the vigilante actions taken by Legion members against Crouch-Hazlett on July 25. The resolution carefully noted that the assembly "did not believe it to be the policy of the American Legion to curb free speech," thus making it easier for the organization to discipline its wayward members. The Socialist Party in Des Moines struck an even more conciliatory tone, offering to send representatives

20. Des Moines News, 7/26/1921; Des Moines Register, 7/26/1921. In 1921 the Argonne Post in Des Moines was the largest in Iowa with 1,852 members. Proceedings of the Third Annual State Convention of the Iowa Department, The American Legion, State Historical Society of Iowa, Iowa City. 
to speak with Argonne Post members to explain the mission of the party and create better understanding between the organizations. The post rebuffed the request and declined to condemn the actions of its members in Crouch-Hazlett's abduction. Local Legionnaires hid behind the logic that the Legion's national headquarters often employed to wriggle out of responsibility for other instances of vigilantism by its members, noting that it saw no need to condemn actions that members perpetrated without authorization or approval by officers. Like national headquarters, the Argonne Post took no steps to discipline or reprimand wayward members. ${ }^{21}$

After speaking in Fort Dodge without incident, CrouchHazlett headed south to Boone for a July 28 oration. There she began her speech from a parked car at an open-air meeting. Her address drew a mixed crowd of supporters, onlookers, and opponents, including members of the local Legion post. In the course of her speech, which was interrupted by jeers from the crowd, Crouch-Hazlett praised aspects of the Soviet government and claimed that President Warren Harding was a "mere figurehead," with Secretary of State Charles Evans Hughes actually running the government. Angered by these comments, local post commander W. H. James jumped onto the running board of Crouch-Hazlett's auto and demanded that she cease speaking. When she refused, Legionnaires helped push her car partly into the street while another woman in the car struck members of the mob with her umbrella in defense. Sympathetic coal miners dragged the car back to the curb and thwarted attempts to attach ropes to its rear bumper. Members of the crowd then started to throw doughnuts and pastries at CrouchHazlett, most of which missed and struck those standing on the other side of her car. At no point did the police observing the speech intervene. Crouch-Hazlett completed her remarks and drove out of town. ${ }^{22}$

21. Des Moines Register, 7/17/1921, 7/28/1921; Des Moines Capital, 8/1/1921; Des Moines Evening Tribune, 8/21/1921; Pencak, For God and Country, 155-56.

22. Des Moines Register, 7/29/1921; Waterloo Evening Courier, 7/29/1921; Ben Gibson to H. C. Shultz, 1/23/1922, ACLU Papers, reel 25, vol. 182; Boone County Pioneer, 7/29/1921; Boone News-Republican, 7/29/1921. 
During her experiences in Iowa in July 1921, Crouch-Hazlett was somewhat incredulous about what was happening to her. "I have been speaking constantly for the Socialist party since the war began, and this is the first disturbance I have encountered," she told reporters in Boone, claiming that on a tour of Iowa the previous fall she had spoken to larger audiences without incident. "The trouble I have met in Iowa," she professed, "came to me like a bolt of lightning out of a clear sky." A reporter in Waterloo later in the summer was as perplexed as she was by her reception. Those who attended her speech expecting a bolshevistic firebrand were bound to be disappointed, the reporter wrote. What they saw and heard, instead, was "a tired, somewhat elderly, motherly-looking woman-more of the schoolmistress in appearance than the professional agitator. . . . There seemed absolutely nothing about either her speech or her manner to indicate why her visit to Iowa should have caused such a furore [sic]." As for the Legionnaires themselves who were hounding her speaking tour, Crouch-Hazlett claimed that, although she had heard of the organization, she knew little about it before this trip to Iowa and had never spoken disrespectfully of it. She dismissed the Legionnaires as "harmless boys . . . inflamed by agitators" and put up to protesting her speeches by local Chambers of Commerce. ${ }^{23}$

In her public comments both to audiences and the press, Crouch-Hazlett demonstrated a keen awareness of the limits the federal government and states had placed on freedom of expression since the war, particularly of those on the left who advocated revolutionary politics. Telling reporters in Des Moines that she believed the Socialist Party's creed "is as good as any other in the land," she noted, "That we are not I.W.W. is shown by the fact that most of the state universities of the coun-

23. Waterloo Evening Courier, 7/30/1921, 8/25/1921; Dubuque Times-Journal, $8 / 28 / 1921$. In truth, the Chamber of Commerce was one of the Legion's greatest adversaries in securing passage of veterans' adjusted compensation legislation. Iowa Legionnaire editor Frank Miles made that precise point in rebutting Socialist W. G. Daniel's claim in the Des Moines press that the Legion had participated in the rail yard raid in Des Moines against suspected IWW members at the behest of the Chamber of Commerce. Jennifer D. Keene, Doughboys, the Great War, and the Remaking of America (Baltimore, 2001), 173-74; Des Moines Register, 7/28/1921. 
try have put in a chair of socialism. We are not here to kill anybody, or have anybody killed. All we are striving to do is to get before the people principles which we believe are right." Part of her struggle was because, she claimed, "Iowa is a greenhorn state when it comes to being alive to progressive questions." The fact that her advocacy for the release of wartime political prisoners and greater relief for the unemployed in the recession of 1921 was drawing such protest clearly surprised her, however. "What I was saying [on July 24 in Des Moines] wasn't half as dangerous as ideas put forth by the democrats and republicans in their campaign speeches. All the countries of Europe have given their political prisoners freedom. The United States should do the same." 24

Crouch-Hazlett saw her confrontations with the Legion as a free speech fight in which critics of her party's political positions tried to deny her a venue from which to promote them. She stopped short of calling the Legionnaires stooges of capitalists and bankers, but her claim that they were encouraged by the Chamber of Commerce to defeat the Socialist agenda suggested that Crouch-Hazlett believed that Legion-led interruptions of her were another effort by the elite to maintain their grip on power. Crouch-Hazlett's rebuttal to her critics was to ask: In a democracy should not all peaceful political ideas carry equal weight and legitimacy?

Others who objected to the Legion's vigilantism during her speaking tour made much the same argument in the summer of 1921. F. B. Wilcox, a self-professed "life long democrat," argued in a letter to the Des Moines Register that the Legion's actions would chill political discourse. "Previous to the war there were thousands of men who did not know a socialist from a Hottentot. Why this sudden pretense of patriotism just because they had a chance to wear a uniform a few months? If this work is allowed to go on, then no man dare open his mouth where a legion holds headquarters." Wilcox concluded, "Socialism is a political creed, and has as much right to be heard as republicanism. The time for arresting a speaker is when he becomes an anarchist and talks treason; then we have a police force we ex-

24. Des Moines Register, 7/25/1921, 7/26/1921. 
pect will do its duty." G. A. Kenderdine, while claiming it was not fair to tar the entire American Legion for the acts of a few, noted in another letter to the Register, "The one lesson [Legionnaires] should have learned is that America's popular sympathy was on the side of the allies because it was believed the Prussian system had set up a military oligarchy that brooked no criticism and true libertarians felt that this system could not live side by side with ours. This same American people will not take kindly to any attempt by individuals to project military caste ideas into our civil life." 25

Iowa Federation of Labor President John L. Lewis echoed this sentiment in a speech to the delegates of the Iowa Legion's state convention on September 1, 1921, after Crouch-Hazlett's tour had run its full course through the state. In the American Federation of Labor (AFL), the Legion had its strongest friend within the labor movement. A relatively conservative association for skilled workers, the AFL endorsed a vision of Americanism that was similar to the Legion's, and the two organizations enjoyed warm relations despite the Legion's antiradical excesses. ${ }^{26}$ Speaking for the Iowa branch of the AFL, Lewis warned the Legion about its growing outlaw status. "I am going to say to you men very frankly that if there is anything that is more zealously guarded by the labor movement than free speech I don't know what it is," he warned the convention. "Now in the last few months, few weeks possibly, the great state of Iowa has been getting some advertising that does not reflect credit on it. I want you to know in the beginning that I hold no brief for this Hazlett woman. I do contend this, that if she is a dangerous character, if she had violated any laws of our land, that simply to take her out for an automobile ride and leave her out on the prairie where she will go into some other city preaching her dangerous doctrine, is not right. If she is wrong I say to you that she should be taken up and punished [by the government]. If she is not, she should not be molested." 27

25. Des Moines Register, 8/3/1921, 8/7/1921.

26. Pencak, For God and Country, 214-16.

27. Proceedings of the Third Annual State Convention of the Iowa Department, The American Legion, Spirit Lake, Iowa, Sept. 1-3, 1921, American Legion Iowa Department Records. 
But Crouch-Hazlett was doing more in Legionnaires' eyes than stumping for socialism. In her speeches she offered a vision for what postwar political culture should be and what political values should define the nation's course in the new peacetime context. The Legion considered socialism's elevation of the interests of one class over another in the political economy a clear violation of its Americanism, but that was only one part of what Legionnaires found objectionable in Crouch-Hazlett's message. Her more particular argument that all should be forgiven from the war and that the nation should return to some state of normalcy by releasing its political prisoners was intolerable to Legionnaires' consideration of loyalty to the nation. Antiwar Socialists had objected to American entrance into the war on the grounds that its suffering would fall disproportionately on the working class. In time of considerable national peril, then, Socialists of Crouch-Hazlett's ilk placed the interests of a class over that of the nation.

S. W. James, the Legionnaire who had stood on CrouchHazlett's car in Boone, bitterly recalled that one of the Socialist critics of his actions in town had gone to jail for expressing that sentiment with the button "not a man or dollar for war." For veterans, who believed that their lives had been imperiled on the front by such disloyalty, such sentiments were personally infuriating. When Crouch-Hazlett and other Socialists called for the release of Debs and other political prisoners simply because the war was over, Legionnaires considered it a confirmation that Socialists believed that loyalty to the state was optional, even during wartime, and that one's extraneous interests could be put ahead of serving the nation. As the country tried to reconstruct its political culture for the postwar era, the Legion believed that the lessons of obligation learned on the battlefield, not in federal jail cells, should be the basis of a new sense of national belonging among citizens. "Treason is treason, whether in war or peace," Iowa Legionnaire editor Frank Miles concluded in the aftermath of the Des Moines incidents. Speech that advocated such principles deserved no protection under the First Amendment of the Constitution, and it was the duty of true patriots to interdict such seditious opinion. "The American Legion is ever on the alert to prevent unAmericanism," Miles claimed. "We have that 
right, and once we believe we are right, we shall strike with all our strength." 28 Legionnaires believed that their wartime service had earned them the right to police the political culture. Those Legion vigilantes who interrupted Crouch-Hazlett did not believe they were interfering with her civil liberties, but rather were performing further service in defending Americanism from destructive influences.

From such references to the war experience, it is clear that Crouch-Hazlett had touched a nerve still raw from wartime for many Iowa Legionnaires. Given Iowa's large German American population, the issue of loyalty had been very significant in the state since the war. In many Iowans' minds, the issue of German Americans' and Socialists' loyalty was undoubtedly linked because of wartime political developments within the state. As German Americans became a political football for the two major political parties, many of them, especially in working-class districts in places such as Davenport, voted increasingly for Socialist candidates in 1916 as a protest against suspicions of their disloyalty. Such actions did little to improve the reputation of either Socialists or German Americans in the minds of "patriotic" Americans. And once the United States entered the fray militarily, both groups bore the brunt of activities designed to overcome lagging public enthusiasm for the war. Surveillance and coercion of suspected disloyalists expanded dramatically. Iowa's broadly written sedition law targeted disloyal German Americans, while the Iowa Liberty Loan Committee, headed by Charles MacNider, Hanford's banker father, found a variety of ways to publicly shame those who had not subscribed. Iowan telephone operators monitored lines for conversations in German, which the state had made illegal. Confrontations between the self-designated loyal and the suspected disloyal were commonplace and often violent. Crouch-Hazlett's experience in Iowa in 1921, therefore, echoed the state's recent past, even if the issue of German loyalty had faded away. ${ }^{29}$

28. Iowa Legionnaire, 8/5/1921, 7/29/1921.

29. Frederick Luebke, Bonds of Loyalty: German-Americans and World War I (DeKalb, IL, 1974), 192, 250-55, 273-81; Nancy Derr, "Lowden: A Study of Intolerance in an Iowa Community During the Era of the First World War," Annals of Iowa 50 (1989), 5-22. 
AS THE LEGION outlined a defense for its actions in late July, Crouch-Hazlett continued her speaking tour largely without incident through early August. As she had promised, she returned to Des Moines on August 4 to deliver the address that had been interrupted twice before. Before a crowd numbering over a thousand, Crouch-Hazlett spoke at the public library where the Legion had abducted her, this time under silent observation by members of the Argonne Post. The American Civil Liberties Union had helped secure police protection for CrouchHazlett, and meetings among city officials, post leaders, and Socialist Party members resulted in a guarantee that her speech would not be interrupted again by Legionnaires. ${ }^{30}$

Legionnaires' rough treatment of Crouch-Hazlett resumed, however, later in August. In Shenandoah on August 11, eight Legionnaires dragged her from the car from which she was speaking to a crowd of 300 and threw her into an awaiting auto. The eight men, led by local post commander Thomas Murphy, held Crouch-Hazlett down as they sped into the country. She later claimed that Murphy had raised his hand threateningly but that when she sarcastically commented on the bravery of eight men beating up a single woman, he resisted striking her. Crouch-Hazlett continued to mock her captors on the 20-mile ride, suggesting that they murder her and leave her body on the side of the road so that their mothers would have sweet memories of their sons' deeds. The Legionnaires finally stopped the car and drove her back into town. "I have faced fiery southern mobs, and have been carried from a courtroom by a triumphant mob, and these things prepared me for dealing with such a barbaric outburst as those of the American Legion in Iowa," she told a United Press reporter about her cool conduct during the abduction. After the incident, Crouch-Hazlett filed a lawsuit against Murphy, the son of a local banker, for $\$ 20,000$ in damages because of the physical nature of the incident. About ten days later in Mason City members of the Salvation Army interrupted Crouch-Hazlett in mid-speech, waving flags and singing "Marching through Georgia." Legionnaires dressed as Ku Klux Klan members suddenly sprang from the crowd and dragged

30. New York Call, 8/6/1921. 
Crouch-Hazlett from her podium in the town park and tossed her into a waiting car. They drove her ten miles into the country and left her on the side of the road. A farmer gave her a ride back to Mason City. ${ }^{31}$

Whether the costumes of Klansmen were meant to mask the participants' true affiliations or represent the veterans' dual membership in both organizations is impossible to determine from the scant evidence available. Given the widespread appeal of anti-Catholicism, calls for "law and order," disappointment in the enforcement of Prohibition, and concern for the nation's apparent slide towards amorality in the 1920s, many Legionnaires likely found enough common cause between the two organizations to join both the Legion and Klan. The Klan drew native-born white Protestant men interested in preserving the social and moral order of the nation as much as its political status quo. Its growth in the Midwest, as historian Leonard Moore has written in his study of the Indiana Klan, represented the "pent-up desires of the white Protestant majority to assert the primacy of its traditional beliefs and its presumed rightful place as the dominant force in community life." Overlap in membership was particularly likely in the Midwest; one Legion report estimated that between 20 and 50 percent of Indiana Legionnaires were also members of the Klan. In Iowa, however, Frank Miles wrote aggressively against the Klan in the Iowa Legionnaire in the early 1920s. Iowa Legionnaires were not certain how many of their own were also members of the Invisible Empire. Some estimates placed the figure as high as 20 percent, but the true figure was probably closer to single digits. ${ }^{32}$

Shared membership by veterans in both the Legion and the Klan does not mean, however, that the organizations were of one mind in their overarching ideologies or uses of vigilantism. Both employed extralegal civic action and used the language

31. New York Call, 8/15/1921, 8/25/1921; Mason City Globe-Gazette, 8/23/1921; Shenandoah Tri-Weekly Sentinel-Post, 8/12/1921; Des Moines News, 8/15/1921; Ida Crouch-Hazlett to Lucille Milner, 8/16/1921, ACLU Papers, reel 25, vol. 182.

32. Leonard J. Moore, Citizen Klansmen: The Ku Klux Klan in Indiana, 1921-1928 (Chapel Hill, NC, 1991), 101; Pencak, For God and Country, 140-42; American Legion, Iowa Department Records, box 7, scrapbook 2. For examples of Miles's attacks on the Klan, see Iowa Legionaire, 9/23/1921, 11/3/1922, and 3/2/1923. 
of "100 percent Americanism," but they were very different in other ways. The Legion endorsed restrictions on immigration during the 1920s, but it had no interest in pursuing the white supremacist and xenophobic vigilantism that the Klan embraced during its postwar heyday. The Legion actually promoted Americanization classes for immigrants to assimilate new arrivals to the values of its civic nationalism and make them "good Americans." Most Legionnaires had no patience, moreover, for the religious bigotry of the Klan fueled by the secret order's belief in a Protestant-centered national identity. Klansmen tended to be from a lower class background than most Legionnaires as well. The Klan drew members from men bitter about the moral depravity of corrupt elites and minoritygroup under-classes. The Legion's national organization gingerly addressed the issue of the Klan so as not to give it undue publicity while not alienating Legionnaires in the Invisible Empire; state and local Legion bodies condemned the organization outright for using vigilantism to support racial and religious bigotry. ${ }^{33}$

The irony of an organization that embraced vigilante tactics condemning another for the same acts indicated that the entire idea of vigilantism's legitimacy was becoming increasingly muddled in 1921. As instances of Legion vigilantism against the radical Crouch-Hazlett continued, Legionnaires debated the wisdom of such a dramatic and confrontational approach to suppressing supposedly disloyal public discourse. No one within the organization openly questioned the legitimacy of monitoring the speeches of orators such as Crouch-Hazlett for disloyalty, but some Legionnaires believed that the incidents of kidnapping and preemptive arrest had gone too far. Legion-

33. Nehls, "A Grand and Glorious Feeling," 186-96; Pencak, For God and Country, 140-43. Recent historical studies of the Klan represent a historiographical turn in the study of the organization. Scholars currently interpret the organization not as a hysterical reaction to social change by members of a declining class but as a populist response to social change that proved flexible and something more than a terrorist ideology. For an overview of this shift toward seeing the Klan as a form of populism, see Leonard J. Moore, "Historical Interpretations of the 1920s Klan: The Traditional View and the Populist Revision," Journal of Social History 24 (1990); and Shawn Lay, Hooded Knights on the Niagara: The Ku Klux Klan in Buffalo, New York (New York, 1995), 177-89. 
naires in Iowa and nationally walked a fine line between their desire to protect Americans from disloyal and dangerous ideas and the need to preserve the public's support for such actions. During the war Americans had accepted the idea that citizens had some level of obligation to monitor the civic conduct and loyalty of their compatriots, seeing private action that supported the state's own policing of loyalty as legitimate. During and after the war, however, it remained unclear what constituted legitimate vigilance and what crossed over to illegitimate action by "the mob." As the criticism the Legion was receiving from some in Iowa indicated, when Legionnaires acted without just provocation to interfere with Crouch-Hazlett's speeches, they crossed the boundary between legitimate and illegitimate civic action and violated her First Amendment rights. ${ }^{34}$

Frank Miles noted that the greatest challenge the Legion faced in the kind of situation Crouch-Hazlett's speeches presented was determining "'what constitutes treasonable statements in peace?' They are not hard to single out in war for then the lines are clear. Who is qualified to judge what should be permitted said and what should not be? Most of us, we must admit, are not." The solution for Legionnaires, Miles argued, was to wait until someone they suspected made disloyal comments about the government actually made them. "A Socialist speaker has to get pretty 'raw' before we have a right to try to close him or her up." 35

Legionnaires in Waterloo made the most concerted effort to clarify exactly what their role in the public sphere of their community should be. After Mason City, Waterloo was next on Crouch-Hazlett's tour. Members of the Becker-Chapman Post asked the city for police protection for Crouch-Hazlett to ensure her safety from mob action and pledged themselves not to interfere with her speech if it remained "within the boundaries of law and order and in no way [was] deprecatory to sound government." A newspaper advertisement inviting the entire community to attend the speech noted, "This is the lady who was arrested in Des Moines, egged in Newton, pied in Boone and

34. Capozzola, “Uncle Sam Wants You," 180-84, 217.

35. Iowa Legionaire, 8/5/1921 . 


\section{NOTICE \\ Ida Croutch Hazlett \\ will talk at}

LINCOLN PARK 7:30, WEDNESDAY, AUG. 24

This is the lady who was arrested in Des Moines, egged in Newton, pied in Boone and kidnaped in Shenandoah. Waterloo will do none of these as we're 100 per cent American and too intelligent.

\section{EVERYBODY INVITED.}

Notice in the Waterloo Evening Courier and Reporter, 8/22/21.

kidnaped in Shenandoah," but affirmed that "Waterloo will do none of these as we're 100 per cent American and too intelligent." The local Legion post also took out ads in local newspapers, reprinting the preamble to the American Legion constitution, which included a pledge to "uphold and defend the Constitution of the United States," and promising that the Legion would not interfere with any speaker whose oration did not violate the preamble's principles. "There is no desire on the part of the American Legion to suppress free speech that does not interpret liberty as license," an officer of the Becker-Chapman Post told a local newspaper. "However, we are definitely committed to our policy of upholding the constitution of the United States. We will not tolerate any propaganda tending to break down national safeguards of liberty." Crouch-Hazlett's speech compared Debs's greatness to that of Abraham Lincoln and described the future for workers under a Socialist American government, but Legionnaires heard no disloyal comments and, according to the local paper, "listened respectfully." 36

On the organization's national level, the Legion began to make similar clarifications of when posts could legitimately intervene to quell radical influence in late 1921, although without repudiating the fundamental need to limit radicals' access to the political process. Into its second full year of existence the Legion

36. Waterloo Evening Courier, 8/23/1921, 8/22/1921, 8/25/1921; Waterloo TimesTribune, 8/24/1921. 


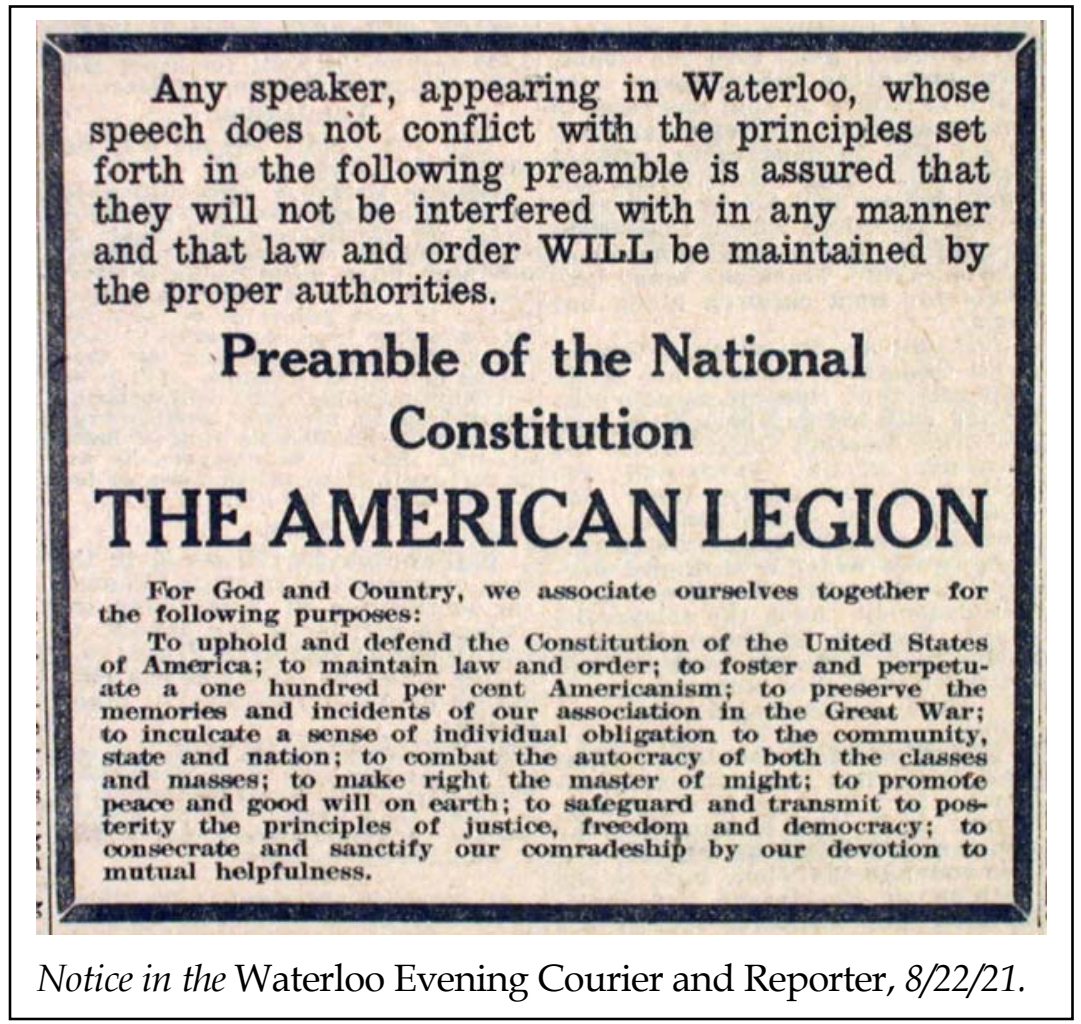

was developing a negative reputation, particularly among liberals, for the kinds of vigilantism members perpetrated in Iowa. ${ }^{37}$ Perhaps more alarmingly to Legion leadership, the organization started to hemorrhage members in 1921. It lost more than 121,000 between Septembers 1920 and 1922, dipping below the 700,000 mark of membership for the first time since its first few months of existence. ${ }^{38}$ Late in 1921 the Legion clarified its stances on

37. The American Civil Liberties Union wrote to the Legion's national headquarters documenting the 50 most egregious cases of Legionnaires' violation of other citizens' civil liberties and demanding that action be taken to rectify the Legion's vigilante tendencies. These instances were widely distributed across the country. Pencak, For God and Country, 154-55.

38. The Legion's antiradical excesses, when combined with its chilly relationship with a large portion of the labor movement and its leadership's continued resistance to soldiers' bonus legislation, contributed to the decline. American Legion, "Third Annual Report of National Officers of The American Legion 
radical politics and civil liberties in the hope of retaining what working-class and liberal-minded membership it had attracted. At its 1921 national convention in Kansas City, the Legion passed a resolution that recognized two methods of political change at work in the United States: "First, through free speech, and a free press leading to changes by the ballot and evolution. Second, through the prostitution of free speech and free press, inciting the people to class consciousness and strife and leading to changes by revolution. The persons and agencies using the latter method are termed radicals." The convention endorsed the first method, "of changing the institutions to be in keeping with the American spirit and constitution," and condemned the second as "unlawful and un-American." 39

That statement implied that the activity of Socialists such as Crouch-Hazlett, when presenting a platform for a political party that resisted talk of "revolution," should be understood by members as consistent with the organization's Americanist principles. The Legion did not retreat at all, though, from its insistence that class-conscious politics and revolutionary rhetoric were anathema to the fundamentals of American national identity and as such deserved no place in American political discourse. The responsibility to interpret the directive and determine whether radicals were using free speech legitimately remained largely in the hands of local posts.

ALTHOUGH THE LEGION did not repudiate vigilantism as a tool for promoting its Americanism, it did seek alternative ways to bring its ideals to American citizens. Confrontation, Legionnaires realized, often brought more attention to radical ideals than any speaker could do on his or her own. Thus, the organization developed educational and social methods to draw Americans to its nationalist understanding without having to rely on the lessons radical counterexamples provided. In 1920

and Legion Publishing Corporation, 1921," 5; American Legion, "Fourth Annual Report of National Officers of The American Legion and Legion Publishing Corporation, 1922," 5, 7.

39. American Legion, Summary of Proceedings of the 3rd National Convention of the American Legion, Oct. 31-Nov. 2, 1921 (Indianapolis, 1921), 39. 
the Legion had created the National Americanism Commission within its national organizational structure. That body was designed to promote Americanism through educational programs and social projects that could put into practice the organization's citizenship value of disinterested service to the common good. Prime among the commission's projects was what the Legion called "civic betterment," a term it derived from a relationship the organization forged in the early 1920s with Community Service, Incorporated, a Progressive-led service organization that promoted recreation reform as a way to foster good citizenship among youth and involve more Americans in the process of democratic governance. Under this idea of civic betterment, Legionnaires supported public health campaigns, adopted Boy Scout troops, worked on traffic safety projects, and provided recreational facilities for community members. Such projects were not separate from the Legion's antiradical agenda, but rather depicted positive visions of what good citizenship should be. They did not rely on the presence of radical others to make their larger point and were therefore more sustainable. As the challenge from socialism and other radical agents waned in the mid- and late-1920s, the Legion increasingly relied on education and civic betterment to spread its Americanist message. ${ }^{40}$

Once again, Iowa members of the American Legion shaped this method of promoting Americanism by their local activism. In 1923 state leaders gathered to form a "Friendly Relations Committee" and hatched the idea for a statewide Community Service Week, to be held between Lincoln's and Washington's birthdays. The idea was the brainchild of Iowa Legion leader Hanford MacNider, who also suggested that posts form community commissions from leaders of other civic organizations. Iowa Legion leaders urged posts to pose the question - "What is the most constructive, helpful, worth while, concrete project that the American Legion can undertake for this community this year?" - to their members and to the community at large through community commissions. The organizers of this plan for greater community involvement in Legion community work dubbed it the "Iowa Idea" and promoted the week energetically

40. Nehls, "A Grand and Glorious Feeling." 


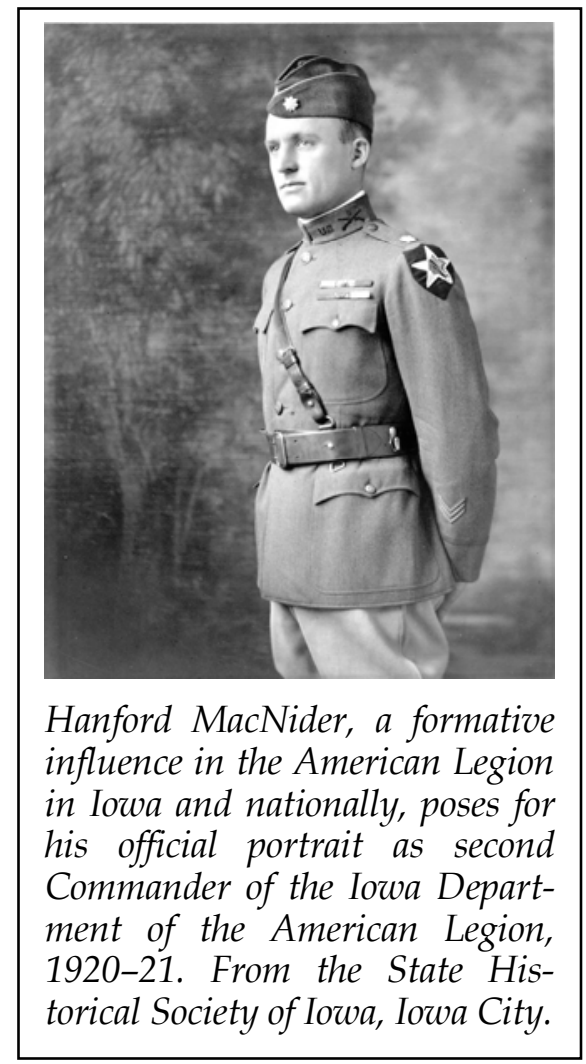

in the state's newspapers. Communities received a wide variety of suggestions, ranging from improving recreational facilities, marking streets with new signs, beginning "city beautiful" and patriotic decoration drives, and adopting Boy Scout troops to starting a campaign against cigarettes. The positive publicity the week garnered for the Legion proved as valuable as any ideas it provided to posts. Speaking in Minnesota about the Iowa Idea, Iowa Department Commander Bert Halligan claimed that such work on civic betterment could work hand-in-hand with Americanism's other focus on defeating Communism in the United States. Halligan urged Minnesotans: "foster better schools, and make your community a more worth-while place in which to live-then you needn't be afraid the communists are going to undermine our government." The national organi- 
zation reacted with enthusiasm to the Iowa plan, establishing a trophy given annually to the department demonstrating the greatest commitment to community service and naming it after MacNider. 41

THE LEGION, though, retained vigilantism in its arsenal of weapons against un-American ideas during the interwar period. As the Iowa examples had demonstrated, Legionnaires used vigilantism most often against out-of-town agitators, whose presence they believed was designed to rile up their local community and expose it to un-American thought. Connecting their local struggle with the broader national one to contain such deleterious influences, Legionnaires reacted to outsiders such as Crouch-Hazlett by disrupting their access to the public sphere. By doing so, Legionnaires reasserted the idea that political participation in the United States had rules to follow based on fealty to the democratic principles and ideas upon which the nation was founded and Americans' common civic identities were based. Events such as the abductions, physical confrontations, and arrests of radicals such as Crouch-Hazlett, which would be repeated by Legionnaires in a variety of contexts and times throughout the nation in the 1920s and 1930s, were designed to dramatize abstract concepts of loyalty and national belonging in a tradition Legionnaires carried over from wartime vigilantism. By the later years of the Great Depression, when labor conflicts rocked the nation, the Legion came to believe that the stakes for the nation's future were high enough to dispense with its concern for the public's opinion of its vigilante efforts.

Episodes such as the ones that transpired in Iowa cities and towns in the summer of 1921 were critical to the development of a modern American nationalism. Aside from the minimal involvement of municipal officials and local police forces, government did not play a role in these confrontations. Determining what it meant to be an American, what kinds of civic and

41. Iowa Legionaire, 1/18/1924, 3/7/1924, 4/1/1924, 4/11/1924, 4/18/1924; Jacob Armstrong Swisher, The American Legion in Iowa, 1919-1929 (Iowa City, 1929), 213. 
political values that identity contained, and what citizens could do to forfeit that identity in their political conduct were largely left to Americans themselves to work out in this period. The American Legion, keenly aware of this fact, attempted to shape American political culture and the rules of political participation in ways that reflected its own ideas of what American nationalism meant. As Iowa Legionnaires demonstrated during the summer of 1921, vigilantism was one way members delineated insiders from outsiders in the national community at the grassroots. Legionnaires' interruptions of Ida Crouch-Hazlett's speaking tour, therefore, serve as a reminder that ideas about the ideological limits of national identity were not simply ephemeral but motivated "patriotic" Americans to take action in their communities.

The disparities of power in the struggle between the Socialist Crouch-Hazlett and vigilante Legionnaires are striking and instructive of how, despite its decentralized nature, American political culture served conservative ends during much of the twentieth century. Legionnaires' constant challenges to the legitimacy not only of the political arguments Crouch-Hazlett presented to her audiences but of her right to present them at all reinforced a conservative, classless vision of American citizenship that backed the existing political power relations among Iowans and Americans more generally. Legion action made it much more difficult for progressive organizations to gain traction in American civic and political life, given that they constantly had to argue for the Americanness of their ideas. Although the Legion's actions supported business interests, its members were motivated by a wider variety of concerns about the future quality of American citizenship they defined in inherently conservative ways. Legionnaires were self-motivated patriots, acting on a shared nationalistic vision. Their disproportionate power within the political culture stands as a testament to the chilling power self-appointed elites can have on American political discourse if their right to speak for all patriotic citizens goes unchallenged. 